\title{
Kualitas Nutrisi Silase Daun Ubi Kayu dengan Penambahan Molases dan Lama Penyimpanan yang Berbeda
}

\section{Nutrition Quality of Cassava Leaves Silage with Different Level of Molases and Storage Time}

\author{
Ayu Lestari ${ }^{1)}$, Anwar Efendi Harahap ${ }^{* 1)}$ dan Wieda Nurwidada Haritsah Zain ${ }^{\text {1) }}$ \\ ${ }^{1)}$ Program Studi Peternakan Fakultas Pertanian dan Peternakan, UIN Sultan Syarif Kasim Riau \\ Jl. H.R. Soebrantas No. 155 Km 15 Tuahmadani Tampan Pekanbaru 28293 \\ *neniannisaharahap@yahoo.co.id
}

\author{
Diterima : o1 Juli 2020 \\ Disetujui : 29 Agustus 2020 \\ Diterbitkan : 31 Agustus 2020
}

\begin{abstract}
Abstrak: Limbah daun ubi kayu dapat menjadi solusi dalam persoalan penyediaan bahan pakan. Penelitian ini bertujuan untuk mengetahui kualitas nutrisi yang terkandung dalam silase daun ubi kayu dengan penambahan molases dan lama penyimpanan yang berbeda. Rancangan yang digunakan dalam penelitian ini yaitu rancangan acak lengkap (RAL) pola faktorial (3×3) dengan 3 ulangan. Faktor A adalah level penambahan molases o\%, $7 \%$, dan 14\%. Faktor B lama penyimpanan o hari, 14 hari, dan 28 hari. Parameter yang diukur adalah bahan kering (\%), protein kasar (\%), lemak kasar(\%), serat kasar (\%), abu (\%) dan BETN (\%). Hasil penelitian menunjukkan bahwa pemberian level molases dan lama penyimpanan mampu menurunkan $(P<0,01)$ bahan kering dan serat kasar serta terjadi interaksi $(P<0,01)$ antara pemberian level molases dan lama penyimpanan pada protein kasar, lemak kasar, dan BETN silase daun ubi kayu. Perlakuan terbaik adalah level molases $14 \%$ dan lama penyimpanan 28 hari karena menurunkan kandungan bahan kering, serat kasar dan meningkatkan BETN silase daun ubi kayu
\end{abstract}

Kata Kunci: daun ubi kayu, lama penyimpanan, molases, nutrisi, silase

Abstract: The cassava leaves waste can be solution in the problem of feed ingredients. The aims of this study were the quality of cassava leaves silage with different molasses levels and storage time. The design used in this research was completely random design factorial (3x3) with 3 replications. Factor A: levels of molases o\%, $7 \%$, and 14\%. Factor B : storage time 0,14 and 28 days. The parameters were dry matter (\%), crude protein (\%), crude fat (\%), crude fiber (\%), ash (\%) and BETN (\%). The results showed that different levels gives of molasses and storage times significant effect $(P<0.01)$ able decreased dry matter and crude fiber and there is interaction $(P$ $<0.01$ ) between of level molases and storage times in crude protein, crude fat and BETN cassava leaves of silage. The best treatment is level of $14 \%$ molasses and 28 days storage times because decreased of dry matter content, crude fiber and increased BETN cassava leaves of silage

Keywords : cassava leaves, molasses, nutrition, silage, storage time

\section{Pendahuluan}

Limbah daun ubi kayu tersedia sepanjang tahun dan dapat menjadi solusi dalam persoalan penyediaan bahan pakan. Daun ubi kayu merupakan tanaman komoditas yang mudah tumbuh sekalipun di tanah yang berpasir atau pada jenis tanah lempeng dengan kandungan bahan organik yang rendah dan temperatur yang tinggi [1]. Berdasarkan data BPS Tahun 2015 bahwa potensi daun ubi kayu di Provinsi Riau sangat melimpah dimana hasil panen ubi kayu di Provinsi Riau pada Tahun 2015 terdapat 3.578 hektar dengan produksi 103.599 ton dengan potensi produksi daun ubi kayu segar sebesar $10-40 \%$ dari tanaman ubi kayu atau setara dengan 10-40 ton/ha/tahun. Tingginya potensi dari tanaman ubi kayu mengakibatkan limbah daun ubi kayu dari tanaman ini juga dapat digunakan dalam pembuatan pakan terutama ternak ruminansia [2], salah satunya dengan proses fermentasi anaerob atau silase

Keberhasilan proses fermentasi secara anaerob dipengaruhi oleh kandungan karbohidrat terlarut dan pengembangan kecocokan seperti penambahan bahan additive, diantaranya kelompok gula yaitu molases. Molases adalah bahan yang mengandung sakarida, merupakan produk samping dari industri gula yang diperoleh setelah dikristalkan dan dipisahkan dari sari gula tebu. Molasses mengandung kadar air berkisar $78-86 \%$, gula $77 \%$, abu $10,5 \%$, protein kasar 3,5\%, dan TDN 72\% [3]. Penambahan molases pada silase dapat meningkatkan populasi 
bakteri asam laktat. Molases digunakan karena dapat menstimulasi perkembangan bakteri pada proses fermentasi dimana karbohidrat terlarut yang tinggi sangat menentukan produksi asam organik di dalam proses ensilase yang dapat mempercepat penurunan derajat keasaman [4]. Prinsip dasar fermentasi adalah mengaktifkan kegiatan mikroba tertentu untuk tujuan merubah sifat bahan agar dihasilkan sesuatu yang bermanfaat dan proses fermentasi yang pada prinsipnya memanfaatkan sejumlah bakteri anaerob (bakteri asam laktat) untuk memproduksi asam laktat sehingga dalam waktu yang singkat $\mathrm{pH}$ mendekati 3,8-4,2 dan fermentasi dibuat dalam silo yaitu kontruksi kedap udara, air dan cahaya yang digunakan untuk menyimpan bahan dengan kadar air lebih dari $65 \%$ [5].

Pembuatan silase bertujuan menghasilkan pakan yang memiliki kandungan bahan kering energi yang stabil serta mudah dicerna dibandingkan dengan tanaman segar [6], selain itu silase daun ubi kayu segar dapat menurunkan kandungan asam sianida. Pengolahan daun ubi kayu segar menjadi silase dapat menurunkan kandungan asam sianida serta penyimpanan selama \pm 2 minggu dengan level molases $12 \%$ proses fermentasi silase biomasa tanaman ubi kayu dapat dikategorikan baik [7]. Penelitian ini bertujuan mengetahui kualitas nutrisi silase daun ubi kayu dengan penambahan molases dan lama fermentasi terhadap kandungan bahan kering (\%), protein kasar (\%), serat kasar (\%), lemak kasar (\%), kadar air (\%), abu dan BETN

\section{Materi dan Metode}

Bahan penelitian yang digunakan adalah daun ubi kayu, molases, aquadest, natrium lauril sulfat, Natrium $\mathrm{NH}_{2}, \mathrm{H}_{2} \mathrm{SO}_{4}, \mathrm{NaOH}$, aseton, heksan, $\mathrm{HCl}$, pelarut, alkohol, indikator. Alat yang digunakan adalah parang,timbangan, alat tulis, sarung tangan, baskom, kantung pastik kedap udara, isolasi, dan alat yang mendukung selama penelitian pemanas, oven, desikator, timbangan analitik, spatula, gelas ukur, pipet tetes, fibertec, tanur listrik, cawan crucible, gelas piala $1.000 \mathrm{~mL}$, buret, destilator, soxhlet, aluminium cup dan Erlenmeyer.

Penelitian ini dilakukan secara eksperimen dengan Rancangan Acak Lengkap (RAL) pola faktorial $(3 \times 3)$ dengan 3 ulangan. Faktor A adalah level penambahan molases terdiri dari o\%, $7 \%$, dan $14 \%$, selanjutnya faktor B yaitu lama penyimpanan o hari, 14 hari, dan 28 hari. Parameter yang diukur dalam penelitian nilai daun singkong menggunakan berbagai penambahan molases dan lama penyimpanan yang berbeda meliputi kadar air (\%), bahan kering (\%), protein kasar (\%),serat kasar (\%), lemak kasar (\%), abu (\%), dan bahan energi tanpa nitrogen (\%).

Prosedur penelitian yaitu daun ubi kayu yang diperoleh dari wilayah perkebunan di Kabupaten
Kampar ditimbang dan dikeringkan dengan matahari selama 2-3 hari pada ruang terbuka, sampai kering merata. Setelah kering udara ditimbang kembali untuk melihat berat keringnya. 1) pencampuran bahan : pencampuran bahan dilakukan dalam baskom dengan mencampurkan limbah daun ubi kayu dengan molases dengan presentase $0 \%, 7 \%, 14 \%$, sehingga semua bahan tercampur homogen, 2) pembungkusan: bahan yang telah tercampur homogen kemudian dimasukkan ke dalam kantong plastik hitam dan dipadatkan sehingga mencapai keadaan anaerob, kemudian diikat dan dilapisi dengan plastik ke-2, kemudian diikat kembali selanjutnya dilapisi kembali dengan plastik ke3,kemudian diikat kembali dan diberi kode sesuai perlakuan, 3) tahap fermentasi: fermentasi ini di lakukan selama o hari / kontrol, 14 hari, 28 hari dalam keadaan anaerob, 4) analisis kandungan nutrisi : analisis proksimat silase daun ubi kayukan dilakukan di Laboratorium. Analisis data : data yang diperoleh dalam penelitian ini diolah dengan rancangan acak lengkap pola faktorial. Bila hasil analisis ragam menunjukkan pengaruh nyata dilakukan uji lanjut dengan Duncan's Multiple Range Test (DMRT).

\section{Hasil dan Pembahasan}

\subsection{Bahan kering}

Rataan kandungan bahan kering silase daun ubi kayu dapat dilihat pada Tabel 1 di bawah ini:

Tabel 1. Rataan kandungan bahan kering silase daun ubi kayu

\begin{tabular}{ccccc}
\hline \multirow{2}{*}{$\begin{array}{c}\text { Level } \\
\text { Molase } \\
(\%)\end{array}$} & \multicolumn{3}{c}{ Lama Penyimpanan (Hari) } & Rataan \\
\cline { 2 - 4 } & 14 Hari & 28 Hari & \\
\hline o\% & $92,11 \pm 0,16$ & $91,15 \pm 0,37$ & $89,27 \pm 1,90$ & $90,84 \pm 0,84^{\mathrm{B}}$ \\
$7 \%$ & $90,74 \pm 0,37$ & $86,14 \pm 2,21$ & $89,47 \pm 1,68$ & $88,78 \pm 1,42^{\mathrm{B}}$ \\
$14 \%$ & $89,19 \pm 1,90$ & $84,66 \pm 4,12$ & $83,00 \pm 1,06$ & $85,61 \pm 2,36^{\mathrm{A}}$ \\
\hline Rataan & $90,68 \pm 0,84^{\mathrm{b}}$ & $87,31 \pm 2,23^{\mathrm{a}}$ & $87,24 \pm 1,54^{\mathrm{a}}$ & \\
\hline
\end{tabular}

Keterangan: Superkrip huruf yang berbeda pada baris yang sama (huruf kecil) dan pada kolom yang sama (huruf besar) menunjukan perbedaan sangat nyata $(\mathrm{P}<\mathrm{o}, \mathrm{ol})$

Terjadinya penurunan bahan kering silase daun ubi kayu dengan penambahan molases kemungkinan disebabkan oleh level pemberian molases yang sudah mencapai optimal. Fungsi molases sebagai sumber energi bagi bakteri asam laktat (BAL) yang berperan dalam proses ensilase dimana BAL mengalami proses regenerasi untuk menghasilkan asam laktat sehingga berpengaruh terhadap kehilangan bahan kering Pernyataan ini diperkuat oleh [8] bahwa kehilangan bahan kering menandakan bahwa bakteri asam laktat memanfaatkan bahan organik untuk memproduksi asam.

Perbedaan lama penyimpanan menunjukan pengaruh sangat nyata $(\mathrm{P}<\mathrm{O}, \mathrm{Ol})$ terhadap penurunan 
kandungan bahan kering. Hal ini kemungkinan diduga penurunan $\mathrm{pH}$ yang sudah optimal pada perubahan bahan kering selama proses ensilase, sehingga mendukung pertumbuhan bakteri asam laktat. Penurunan kandungan bahan kering hingga lama penyimpanan 28 hari menunjukkan bahwa bakteri asam laktat memanfaatkan substrat Water Soluble Carbohydrat (WSC) untuk memproduksi asam laktat, asam laktat ini akan berperan dalam penurunan $\mathrm{pH}$ silase [9].

\subsection{Protein kasar}

Rataan kandungan Protein Kasar silase daun ubi kayu dapat dilihat pada Tabel 2 berikut ini:

Tabel 2. Rataan kandungan protein kasar silase daun ubi kayu

\begin{tabular}{cccc}
\hline Level & \multicolumn{3}{c}{ Lama Penyimpanan (Hari) } \\
\cline { 2 - 4 } $\begin{array}{c}\text { Molase } \\
(\%)\end{array}$ & o Hari & 14 Hari & 28 Hari \\
\hline $0 \%$ & $24,86 \pm 1,40^{\mathrm{cB}}$ & $10,41 \pm 1,35^{\mathrm{Aa}}$ & $20,84 \pm 2,19^{\mathrm{bA}}$ \\
$7 \%$ & $9,98 \pm 1,51^{\mathrm{aA}}$ & $19,97 \pm 2,31^{\mathrm{bB}}$ & $30,51 \pm 2,42^{\mathrm{cC}}$ \\
$14 \%$ & $25,31 \pm 1,73^{\mathrm{bB}}$ & $21,13 \pm 1,94^{\mathrm{ab}}$ & $25,01 \pm 0,67^{\mathrm{Bb}}$ \\
\hline
\end{tabular}

Keterangan: Superksrip huruf yang berbeda pada baris yang sama (huruf kecil) dan pada kolom yang sama (huruf besar) menunjukan perbedaan sangat nyata $(\mathrm{P}<0,01)$

Terjadi Interaksi antara level molases dan lama penyimpanan juga berbeda sangat nyata $(\mathrm{P}<\mathrm{O}, \mathrm{Ol})$ terhadap perubahan kandungan protein kasar pada silase daun ubi kayu. Level molases $7 \%$ dan lama penyimpanan 28 hari pada silase daun ubi kayu menghasilkan kandungan protein kasar lebih baik (30,51\%) dibandingkan dengan perlakuan kombinasi lainnya. Hal ini diduga disebabkan terjadi proses proteolisis dimana protein dipecah menjadi asam amino melalui bantuan kinerja enzim. Hal ini sesuai dengan pernyataan [10] bahwa mikroba yang mempunyai pertumbuhan dan perkembangbiakan yang baik dapat mengubah lebih banyak komponen penyusun media menjadi satu massa sel sehingga akan terbentuk protein yang berasal dari tubuh mikroba itu sendiri dan pada akhirnya akan meningkatkan protein kasar pada silase.

Kandungan protein kasar ini lebih tinggi dibandingkan dengan penelitian yang dilaporkan oleh [11] pada silase daun ubi kayu selama fementasi 6o hari menggunakan Lactobabcillus plantarum dan Lactobacillus ramnosus menghasilkan protein kasar yaitu $13,78 \%$ dan $14,90 \%$

\subsection{Lemak kasar}

Rataan kandungan lemak kasar silase daun ubi kayu dapat dilihat pada tabel 3
Tabel 3. Rataan kandungan lemak kasar silase daun ubi kayu

\begin{tabular}{cccc}
\hline Level & \multicolumn{3}{c}{ Lama Penyimpanan (Hari) } \\
\cline { 2 - 4 } $\begin{array}{c}\text { Molases } \\
(\%)\end{array}$ & o Hari & 14 Hari & 28 Hari \\
\hline o\% & $9,99 \pm 0,02^{\mathrm{cB}}$ & $4,15 \pm 0,05^{\mathrm{aC}}$ & $4,99 \pm 0,03^{\mathrm{bB}}$ \\
$7 \%$ & $8,86 \pm 0,16^{\mathrm{Ca}}$ & $3,43 \pm 0,07^{\mathrm{aB}}$ & $4,46 \pm 0,15^{\mathrm{bA}}$ \\
$14 \%$ & $10,19 \pm 0,01{ }^{\mathrm{cB}}$ & $2,78 \pm 0,05^{\mathrm{aA}}$ & $6,72 \pm 0,03{ }^{\mathrm{bC}}$ \\
\hline
\end{tabular}

Keterangan: Superkrip huruf yang berbeda pada baris yang sama (huruf kecil) dan pada kolom yang sama (huruf besar) menunjukan perbedaan sangat nyata $(\mathrm{P}<0,01)$

Terjadi interaksi antara level molases dan lama penyimpanan juga berbeda sangat nyata $(\mathrm{P}<\mathrm{O}, \mathrm{O} 1)$ terhadap perubahan kandungan lemak kasar pada silase daun ubi kayu. Peningkatan level molases 14\% dan lama penyimpanan o hari menghasilkan kandungan lemak kasar yang tinggi (10,19\%) dibandingkan kombinasi perlakuan lainnya. Hal ini diduga bahwa semakin banyak level penambahan molases akan meningkatkan kandungan lemak kasar pada silase daun ubi kayu. Pada proses silase bakteri yang berkembang adalah BAL yang menghasilkan asam laktat dan bukan menghasilkan enzim lipase. Hal ini sesuai dengan yang disampaikan [12] yang menyatakan fermentasi silase yang baik didominasikan oleh BAL dan menghasilkan konsentrasi asam organik yang didominasikan oleh asam laktat.

Kandungan lemak kasar pada penelitian ini lebih tinggi dibandingkan penelitian yang dilaporkan [13] pada daun ubi kayu yang difermentasi menggunakan $\mathrm{EM}_{4}$ hingga $4 \mathrm{ml}$ serta penambahan dedak pada taraf o\% dan $10 \%$ menghasilkan kandungan lemak kasar berkisar antara $4,48-4,58 \%$

\subsection{Serat kasar}

Rataan kandungan serat kasar silase dapat dilihat pada Tabel 4 dibawah ini:

Tabel 4. Rataan kandungan serat kasar silase daun ubi kayu

\begin{tabular}{|c|c|c|c|c|}
\hline \multirow{2}{*}{$\begin{array}{c}\text { Level } \\
\text { Molases } \\
(\%)\end{array}$} & \multicolumn{3}{|c|}{ Lama Penyimpanan (Hari) } & \multirow{2}{*}{ Rataan } \\
\hline & o Hari & 14 Hari & 28 Hari & \\
\hline o\% & $20,06 \pm 1,53$ & $18,29 \pm 0,77$ & $16,62 \pm 1,78$ & $18,32 \pm 1,36^{C}$ \\
\hline $7 \%$ & $18,36 \pm 0,77$ & $16,11 \pm 1,09$ & $15,75 \pm 1,51$ & $16,74 \pm 1,12^{\mathrm{B}}$ \\
\hline $14 \%$ & $17,55 \pm 1,35$ & $14,54 \pm 2,23$ & $12,88 \pm 0,78$ & $14,99 \pm 1,45^{\mathrm{A}}$ \\
\hline Rataan & $18,65 \pm 1,21^{\mathrm{c}}$ & $16,31 \pm 1,36^{b}$ & $15,08 \pm 1,35^{\mathrm{a}}$ & \\
\hline
\end{tabular}

Tabel 4. memperlihatkan bahwa perlakuan penambahan molases memberikan pengaruh sangat nyata $(\mathrm{P}<\mathrm{O}, \mathrm{Ol})$ terhadap kandungan serat kasar yang dihasilkan. Lama penyimpanan sangat nyata $(\mathrm{P}<\mathrm{O}, \mathrm{O} 1)$ terhadap kandungan serat kasar yang dihasilkan. 
Tidak terjadi interaksi antara level penambahan molases dan lama penyimpanan terhadap peningkatan kandungan serat kasar $(\mathrm{P}>0,05)$. Penurunan kandungan serat kasar pada perlakuan silase dengan penambahan molases $14 \%$ diduga disebabkan molases sebagai sumber energi bagi bakteri asam laktat (BAL) yang berperan dalam proses ensilase, sehingga berimplikasi terhadap penurunan kandungan serat kasar pada silase. Hal ini sesuai oleh [14] yang menyatakan bahwa serat kasar dipengaruhi oleh kandungan NDF dan ADF yang merupakan komponen dari serat.

Kandungan serat kasar pada penelitian ini berkisar antara 12,88 - 20,06\% lebih tinggi dibandingkan penelitian yang dilaporkan [15] pada silase daun ubi kayu dengan penambahan dedak padi dan tepung jagung pada perbandingan $\mathrm{C} / \mathrm{N}$ 17,88; 18,88; 19,88 dan 20,88 menghasilkan kandungan serat kasar berikisar 11,29 - 17,57\%. Hampir sama dengan penelitian yang dilaporkan [16] pada silase perbandingan daun dan akar ubi kayu pada taraf 50\%:50\%; 60\%:40\%; 70\%:30\% dan 80\%; $20 \%$ menghasilkan kandungan serat kasar berkisar antara $18,00-22,00 \%$

\subsection{Kadar abu}

Rataan kandungan kadar abu silase daun ubi kayu dapat dilihat pada Tabel 5 dibawah ini:

Tabel 5. Rataan kandungan kadar abu silase daun ubi kayu

\begin{tabular}{ccccc}
\hline \multirow{2}{*}{$\begin{array}{c}\text { Level } \\
\text { Molases }\end{array}$} & \multicolumn{3}{c}{ Lama Penyimpanan (Hari) } & \\
\cline { 2 - 4 }$(\%)$ & o Hari & 14 Hari & 28 Hari & Rataan \\
\hline $0 \%$ & $6,89 \pm 0,10$ & $7,52 \pm 0,2$ & $7,28 \pm 0,82$ & $7,23 \pm 0,38^{\mathrm{B}}$ \\
$7 \%$ & $6,27 \pm 0,14$ & $6,75 \pm 0,21$ & $6,94 \pm 0,22$ & $6,66 \pm 0,19^{\mathrm{A}}$ \\
$14 \%$ & $6,56 \pm 0,05$ & $7,22 \pm 0,46$ & $7,54 \pm 0,23$ & $7,11 \pm 0,24^{\mathrm{B}}$ \\
\hline Rataan & $6,58 \pm 0,09^{\mathrm{a}}$ & $7,17 \pm 0,3^{\mathrm{b}}$ & $7,26 \pm 0,42^{\mathrm{b}}$ & \\
\hline
\end{tabular}

Keterangan: Superskrip huruf yang berbeda pada baris yang sama (huruf besar) dan pada kolom yang sama (huruf kecil) menunjukan perbedaan sangat nyata $(\mathrm{P}<\mathrm{o}, \mathrm{ol})$

Penambahan level molases $7 \%$ mengakibatkan terjadi penurunan kandungan abu dan mengalami kenaikan kembali pada level 14\%. Hal ini kemungkinan disebabkan meningkatnya kandungan bahan organik pada level molases $14 \%$ sehingga berpengaruh terhadap kandungan abu yang dihasilkan pada silase. Hal ini sesuai dengan yang disampaikan oleh [17] bahwa kandungan abu berkaitan dengan bahan anorganik berupa mineralmineral, dengan demikian bila bahan organik (abu) turun, maka diduga kandungan bahan organik yang mengandung zat-zat nutrisi yang cukup penting, seperti protein, lemak, karbohidrat dan vitamin semakin meningkat.
Kandungan abu pada penelitian ini berkisar antara 6,2 - 7,54\% hampir sama dengan penelitian yang dilaporkan [18] pada silase daun ubi kayu yang difermentasi dengan $\mathrm{EM}_{4}$ serta penambahan dedak padi menghasilkan kadar abu berkisar 6,25-7,73\%, serta juga hampir sama dengan penelitian yang dilaporkan [19] pada silase biomassa tanaman ubi kayu (kulit umbi, batang dan daun) yang difermentasi hingga 6 minggu dengan penambahan molases $12 \%$ menghasilkan kadar abu berkisar antara $6,03-6,56 \%$

\subsection{Bahan Ekstrak Tanpa Nitrogen}

Rataan kandungan BETN silase daun ubi kayu dapat dilihat pada Tabel 6 berikut ini:

Tabel 6. Rataan kandungan BETN silase daun ubi kayu

\begin{tabular}{cccc}
\hline $\begin{array}{c}\text { Level } \\
\text { Molases } \\
(\%)\end{array}$ & \multicolumn{3}{c}{ Lama Penyimpanan (Hari) } \\
\cline { 2 - 4 } & $0 \%$ & 14 Hari & 28 Hari \\
\hline $7 \%$ & $58,69 \pm 0,73^{\mathrm{cB}}$ & $48,23 \pm 1,90^{\mathrm{aA}}$ & $59,46 \pm 3,46^{\mathrm{Ba}}$ \\
& & & \\
& & & \\
& & & \\
$14 \%$ & $69,42 \pm 2,04^{\mathrm{bB}}$ & $60,01 \pm 0,77^{\mathrm{aB}}$ & $68,16 \pm 1,23^{\mathrm{Bb}}$ \\
\hline
\end{tabular}

Keterangan: Superkrip huruf yang berbeda pada baris yang sama (huruf kecil) dan pada kolom yang sama (huruf besar) menunjukan perbedaan sangat nyata $(\mathrm{P}<0,01)$

Terjadi peningkatan kandungan BETN pada perlakuan lama penyimpanan 28 hari dengan penambahan level molases $14 \%$ sebesar $68,16 \%$. Kenaikan kandungan BETN pada silase daun ubi kayu disebabkan BAL telah optimal dalam memanfaatkan kandungan substrat yang ada pada silase daun ubi kayu dengan penambahan molases, terutama komponen monosakarida yang mudah larut dalam air, hal ini memudahkan bakteri asam laktat menggunakan karbohidrat mudah larut untuk menghasilkan asam laktat, hal ini berimplikasi terhadap peningkatan kandungan BETN. Pendapat ini diperkuat oleh [20] yang menyatakan bahwa bakteri asam laktat mempunyai kemampuan untuk, memfermentasikan gula menjadi asam laktat.

Kandungan BETN pada penelitian ini lebih tinggi dibandingkan penelitian yang dilaporkan [21] pada silase daun ubi kayu dengan penambahan dedak padi dan jagung giling menghasilkan kandungan BETN dengan kisaran 51,13- 58,04\%

\section{Kesimpulan}

Perlakuan terbaik dalam penelitian ini terdapat pada level molases $14 \%$ dan lama penyimpanan 28 hari karena dapat menurunkan kandungan bahan kering, serat kasar dan meningkatkan BETN silase daun ubi kayu. 


\section{Referensi}

[1] Wanapat and M. Role Of Cassava Hay as Animal Feed in The Tropics. Proc. Int. Workshop Current Research and Development on Use of Cassava as Animal Feed, Thailand. Pp. 13-20, 2001

[2] Sirait J dan Simanihuruk K . Potensi dan Pemanfaatan Daun Ubikayu Dan Ubi Jalar sebagai Sumber Pakan Ternak Ruminansia Kecil.Wartazoa, 20(2):75-84, 2010

[3] Utomo R, Soejono M, Widyobroto BP and Sudirman. Determination of In Vitro Digestibility of Tropical Feeds Using Cattle Faeces as Rumen Fluid Alternative. Media Peternakan. 34 (3): 207-211, 2011

[4] Smith, J.M. Chemical Engineering Kinetic's. 3rd Ed. Mc Graw HillmBook Kagakusha, Tokyo, 1973

[5] Hanafi, N. D. Perlakuan Silase dan Amoniasi Daun Kelapa Sawit Sebagai Bahan Baku Pakan Domba. Laporan Penelitian. Fakultas PertanianProgram Studi Produksi Ternak Universitas Sumatera Utara, 2004

[6] Kung Jr L, Shaver RD, Grant RG and Schmidt§ RJ. Silage Review: Interpretation of Chemical, Microbial and Organoleptic Components of Silages. J. Dairy Sci. 101:4020-4033, 2018

[7] Simanihuruk K, Sirait J dan Syawal M. Penggunaan Silase Biomassa Tanaman Ubi Kayu (Kulit Umbi, Batang, Dan Daun) Sebagai Pakan Kambing Peranakan Etawah (PE). Pastura, 2(2): 79-83, 2012

[8] Lendrawati, Ridla M dan Ramli N. Kualitas Fermentasi dan Nutrisi Silase Ransum Komplit Berbasis Jagung, Sawit Dan Ubi Kayu In Vitro. Seminar Nasional Teknologi Peternakan dan veteriner. Program Pascasarjana Fakultas Peternakan, Institut Pertanian Bogor, Bogor. 2008

[9] Ennahar S, Cai Y and Fujita Y. Phylogenetic Diversity of Lactic Acid Bacteria Associated with Paddy Rice Silage As Determined By $16 \mathrm{~S}$ Ribosomal DNA Analysis. Applied and Environmental Microbiology, 69 (1): 444-451, 2003

[10] Sukara E dan Atmowidjojo. Pemanfaatan Ubi Kayu Untuk Produktifitas Enzim Amylase dan Protein Sel Tunggal; Optimasi Nutrisi untuk Proses Fermentasi Substrat Cair dengan Menggunakan Kapang hizopus. Seminar Nasional UPT-EPG. Lampung, 1980

[11] Napasirth V, Napasirth P, Sulinthone T, Phommachanh $\mathrm{K}$ and Cai Y. Microbial
Population, Chemical Composition and Silage Fermentation Of Cassava Residues. Animal Science Journal, 86: 842-848, 2015

[12] Chen, Y and Weinberg Z.G. Changes During Aerobik Exposure of Wheat Silages. Anim. Feed Sci and Tech, 154:76-82, 2008

[13] Santoso U dan Aryani I. Perubahan Komposisi Kimia Daun Ubi Kayu yang Difermentasi oleh Em4. Jurnal Sain Peternakan Indonesia, 2(2): 5356, 2007

[14] Septian F, Kardaya D dan Astute KD. Evaluasi Kualitas Limbah Sayur Pasar yang Diperkaya dengan Berbagai Adiftif dan Bakteri Asam Laktat. Jurnal Pertanian Jurusan Peternakan Fakultas Agribisnis dan Teknologi Paangan Universitas Djuanda Bogor, 2011

[15] Noviadi R, Zairiful and Candra A.A. Improvement of Carbon-To-Nitrogen $(\mathrm{C} / \mathrm{N})$ Ratio by Making Cassava Leaf Silage and its Implications in Digestibility in Goat. Bangl. J. Vet. Med. 15 (2): 127-132, 2017

[16] Amos AT, Idowu OMO, Oso AO, Durojaiye OJ, Agazue K and Adebowale AA. The Chemical Composition, Anti-nutritional and Microbial Properties of Ensiled Cassava Root-Leaf Blends as Potential Feed in Swine Diet. Pertanika J. Trop. Agric, 42 (4): 1219 - 1235, 2019

[17] Tillman, A. D., H. Hartadi., S. Reksohadiprodjo dan Ledbosoekojo S. Ilmu Makanan Ternak Dasar. Gadja Mada University Press. Yogyakarta, 1989

[18] Santoso U dan Aryani I. Perubahan Komposisi Kimia Daun Ubi Kayu yang Difermentasi oleh EM4. Jurnal Sain Peternakan Indonesia, 2(2): 5357, 2007

[19] Simanihuruk, K, Sirait J dan Syawal M. Penggunaan Silase Biomassa Tanaman Ubi Kayu (Kulit Umbi, Batang dan Daun) Sebagai Pakan Kambing Peternakan Etawah (PE), Sei Putih. Pastura 2(2)5: 79-83, 2012

[20] Santi RKD,Widyawati WPS dan Suprayogi. Kualitas dan Nilai Nutrisi Kecernaan In-Vitro Silase Batang Pisang (Musa Paradiseaca) dengan Penambahan Akselotar. Jurnal Tropical Animal Husbandry. 1(1):15-23, 2011

[21] Noviadi R dan Zairiful. Profile Nutrisi Silase Daun Singkong dengan Tingkat Protein Kasar yang Berbeda pada Substrat. Prosiding Seminar Nasional Pengembangan Teknologi Pertanian. Politeknik Negeri Lampung, 2016 